\title{
Modulation of Biochemical and Haematological Indices of Silver Carp (Hypophthalmichthys molitrix Val.) Exposed to Toxic Cyanobacterial Water Bloom
}

\author{
Radovan Kopp ${ }^{1,2 *}$, Miroslava Palíková3 ${ }^{3}$ Stanislav Navrátil ${ }^{3}, Z_{\text {deněk Kubíček }}^{4}$, Andrea \\ Ziková $^{1,2}$, Jan Mareš ${ }^{1}$ \\ ${ }^{1}$ Department of Fisheries and Hydrobiology, Mendel University in Brno, Czech Republic \\ ${ }^{2}$ Institute of Botany, Czech Academy of Sciences, Brno, Czech Republic \\ ${ }^{3}$ Department of Veterinary Ecology and Environmental Protection, University of Veterinary and Pharmaceutical \\ Sciences, Brno, Czech Republic \\ ${ }^{4}$ Department of Clinical Biochemistry, Hospital Třinec, Třinec, Czech Republic
}

Received December 17, 2008

Accepted June 30, 2009

\begin{abstract}
The aim of this study was to evaluate the influence of toxic cyanobacterial water bloom on the blood indices of two-year-old silver carp (Hypophthalmichthys molitrix Val.). Experimental fish (336 $\pm 32 \mathrm{~mm}$ length, $365 \pm 112 \mathrm{~g}$ weight) were exposed to a natural population of cyanobacterial water bloom (mainly Microcystis aeruginosa and M. ichthyoblabe) that contained microcystins (total concentration 133-284 $\mu \mathrm{g}^{-\mathrm{g}^{-1}}$ (DW), concentration in water $\left.2.8-7.4 \mu \mathrm{g} \cdot 1^{-1}\right)$. Haematological indices showed marked changes in fish exposed to the cyanobacterial population compared to the control group. Statistical evaluation of the influence of cyanobacterial water bloom on biochemical and haematological indices of silver carp showed a distinct decrease of albumin, alkaline phosphatase, cholesterol, glucose, total protein, creatinine, lactate, lactate dehydrogenase, phosphorus, iron, cholinesterase, haemoglobin, haematocrit, erythrocyte and leukocyte compared to the control. Values of alanine aminotransferase were significantly increased compared to the control. After exposure to the cyanobacterial water bloom, the silver carp were kept in pure water for monitoring the persistence of biochemical and haematological indices. Influence of the cyanobacterial population on values of albumin, alkaline phosphatase, cholesterol, total protein, glucose, creatinine, phosphorus, iron, cholinesterase, erythrocyte and haematocrit persisted up to 28 days after the end of exposure. Duration of exposure, toxicity and density of cyanobacterial water bloom had an important impact on individual biochemical and haematological indices.
\end{abstract}

Fish, haematology, cyanobacteria, biochemical indices, microcystins

Eutrophication of aquatic ecosystems is accompanied by cyanobacterial mass development, representing serious environmental problems. Cyanobacteria, as photosynthesizing organisms, produce biologically active compounds that may affect the growth and development of other water organisms, and the physical and chemical characteristics of water (Chorus et al. 2000). Much attention has been paid recently to the impact of cyanobacterial toxins on fish (Landsberg 2002).

The influence of cyanotoxins on fish following experimental intoxications or the impact of an environment containing cyanotoxins on fish have been studied by a number of authors using clinical, morphological, histological, ultrastructural, haematological and biochemical methods. One of the most common genera of cyanobacterial water bloom is Microcystis, the producer of hepatotoxic microcystins (MCs) that can occasionally occur at high concentrations in shallow waters and may induce injury to fish. A complete summary of the effects of microcystins on fish was provided by Malbrouck and Kestemont (2006). Majority of toxins are absorbed into the fish organism through the gastrointestinal tract, whereas toxin penetration through the skin or gills is negligible (Tencalla et al. 1994). It has been suggested that phytoplanktonophagous fish species are more affected

Address for correspondence:

Ing. Radovan Kopp, Ph.D.

Department of Fisheries and Hydrobiology

Mendel University in Brno

Zemědělská 1, 61300 Brno, Czech Republic
Phone: +420 545133268

Fax: +420 545133267

E-mail: fcela@seznam.cz

http://www.vfu.cz/acta-vet/actavet.htm 
by cyanobacterial toxins due to higher digestion of cyanobacterial water bloom (Carbis et al. 1997; Vajcová et al. 1998). On the other hand, experiments with silver carp proved its strong resistance to toxic Microcystis and MCs (Shen et al. 2005).

Lysates of cyanobacterial biomass administered per os or intraperitoneal exposure of pure microcystins cause significant changes of biochemical indices, red blood cells and plasma enzyme activities. Microcystins cause liver tissue damage in fish, demonstrated by a significant increase of alanine aminotransferase (ALT), aspartate aminotransferase (AST) and lactate dehydrogenase (LDH) activities (Rabergh et al. 1991; Navrátil et al. 1998; Vajcová et al. 1998).

The rate of LDH, ALT and AST increase depends on the route of administration, characteristics of the cyanobacterial biomass and the amount of toxin. Toxins are synthesized during the growth phase of cyanobacteria and large quantities of microcystins are released into the water during the collapse of the bloom or from actively growing cyanobacterial populations (Malbrouck and Kestemont 2006). Chorus and Bartram (1999) showed that $100 \%$ of toxins are located in the cells of young populations of cyanobacteria whereas in decaying cells, toxin concentrations in water rose to values of $70-80 \%$.

Fish exposed to media containing dispersed microcystins demonstrated that toxic effects are time-delayed due to limited penetration into the healthy fish. The toxic effect after oral administration is approximately $10 \times$ weaker than after intraperitoneal application (Carbis et al. 1997).

The long-term impact of cyanobacteria containing microcystins at lower concentrations is relatively difficult to observe in individual fish, therefore control of more individuals in fish population is more useful. The measurement of aminotransferases (ALT, AST), bile acids, bilirubin, sodium and chloride from the blood serum is recommended (Carbis et al. 1996).

Biochemical indices of blood and plasma in fish are affected by many endogenous and exogenous factors. The changes of haematological and biochemical indices in fish could be caused by chemical factors (Kopp and Heteša 2000; Lusková et al. 2002; Pepeljnjak et al. 2003), age, health and body condition (Svetina et al. 2002), nutrition (Serpunin 1995) or stress (Dobšíková et al. 2006).

The aim of this work was to study the effects of natural cyanobacterial population with a known amount of microcystins on the biochemical and haematological indices of two-yearold silver carp (Hypophthalmichthys molitrix Val.) and their persistence in pure water.

\section{Materials and Methods}

Fish

Two-year-old silver carp (Hypophthalmichthys molitrix Val.) obtained from a single artificial stripping (Fishpond management Pohořelice, Czech Republic) were used for the experiment. These fish measured $336 \pm$ $32 \mathrm{~mm}$ in length, and had an average body weight of $365 \pm 112 \mathrm{~g}$. They were acclimatised for one week before the start of the study in a small pond without cyanobacteria. They were caged and exposed to a cyanobacterial bloom that had naturally developed in the breeding pond during 28 days from August to October 2005. In parallel, control groups of fish were also kept in another pond without apparent cyanobacterial bloom formation. The fish were reared under natural conditions without additional feeding. After exposure, they were placed in pure water for the same period of time ( 28 days) for monitoring the persistence of biochemical indices. Influences of the cyanobacterial population on the values of ALB, ALP, CHOL, TP, GLC, CRE, P, Fe and CHE in the silver carp were monitored for 28 days after exposure. The fish were placed into two 1000-1 tanks containing dechlorinated drinking water (pure water) without feeding. The fish were exposed to a $12-\mathrm{h}$ light/12h dark photoperiod, and the tank water was changed daily. The water variables during the experiments (given for the experimental and control group, respectively) were as follows: water temperature $19.2 \pm 1.1,19.6 \pm 1.1{ }^{\circ} \mathrm{C}$; dissolved oxygen 10.0 $\pm 3.2,11.1 \pm 2.8 \mathrm{mg} \cdot 1^{-1} ; \mathrm{pH} 8.9 \pm 0.6,9.1 \pm 0.2$, ammonia $0.38 \pm 0.14,0.45 \pm 0.14 \mathrm{mg} \cdot \cdot^{-1} \mathrm{~N}_{-} \mathrm{NH}_{4}^{+}$, and nitrite $0.058 \pm 0.010,0.070 \pm 0.011 \mathrm{mg} \cdot \mathrm{l}^{-1} \mathrm{~N}-\mathrm{NO}_{2}$. Water saturation by oxygen, temperature and $\mathrm{pH}$ were measured by a WTW Oxi 340i dissolved oxygen meter and a WTW pH $340 \mathrm{i} \mathrm{pH}$ meter. Ammonium ions were determined by the Nessler method and nitrites by a method using N-(1-naphthyl)-ethylenediamine (APHA 1981).

Phytoplankton and microcystins

Cyanobacterial and algal biomass was evaluated every week by chlorophyll $a$ concentrations (ISO 10260 , 
1992) and by the number of cells counted in Bürker's counting chamber. Cyanobacterial biomass (dominated coccal Microcystis aeruginosa and $M$. ichthyoblabe) estimated by the chlorophyll $a$ cell concentration varied from 198 to $598 \mu \mathrm{g} \cdot \mathrm{l}^{-1}\left(3.9-6.0 .10^{5}\right.$ cells $\left.\cdot \mathrm{ml}^{-1}\right)$ in the experimental pond. The algal biomass (dominated by chlorococcal green algae - genus Scenedesmus and Coelastrum) also estimated by the chlorophyll $a$ cell concentration, varied from 216 to $445 \mu \mathrm{g} \cdot \mathrm{l}^{-1}\left(1.3-5.4 .10^{4}\right.$ cells $\left.\cdot \mathrm{ml}^{-1}\right)$ in the control pond.

Concentrations of microcystins in the cyanobacterial and algal biomass were determined by the previously published method using HPLC (Agillent 1100 system, Supelcosil ABZ+Plus C18 column) coupled with a photodiode array detector (Bláha and Maršálek 2003). The concentrations of microcystins in the experimental and control breeding pond are presented in Table 1. The concentrations are well comparable with microcystin levels from other ponds in the Czech Republic (Maršálek et al. 2001).

Table 1. Microcystin concentrations during the experiment.

(DW - dry weight, IC - intracellular, EC - extracellular, LOD - limit of detection, $0.05 \mu \mathrm{g} \cdot \mathrm{l}^{-1}$ )

\begin{tabular}{|c|c|c|c|c|c|c|c|c|c|}
\hline \multirow{3}{*}{$\begin{array}{l}\text { Duration of } \\
\text { experiment } \\
\text { (days) }\end{array}$} & \multicolumn{8}{|c|}{ Experimental pond } & \multirow{3}{*}{\begin{tabular}{|c} 
Control \\
\begin{tabular}{|c|} 
IC $+\mathrm{EC}$ \\
$\left(\mu \mathrm{g} \cdot l^{-1}\right)$
\end{tabular} \\
total \\
\end{tabular}} \\
\hline & \multicolumn{2}{|c|}{$\begin{array}{l}\text { In biomass } \\
\left(\mu \mathrm{g} \cdot \mathrm{g}^{-1}\right) \mathrm{DW}\end{array}$} & \multicolumn{2}{|c|}{$\begin{array}{c}\text { IC } \\
\left(\mu \mathrm{g} \cdot \mathrm{l}^{-1}\right)\end{array}$} & \multicolumn{2}{|c|}{$\begin{array}{c}\mathrm{EC} \\
\left(\mu \mathrm{g} \cdot \mathrm{l}^{-1}\right)\end{array}$} & \multicolumn{2}{|c|}{$\begin{array}{r}\mathrm{IC}+\mathrm{EC} \\
\left(\mu \mathrm{g} \cdot \mathrm{l}^{-1}\right)\end{array}$} & \\
\hline & MC-LR & total & MC-LR & total & MC-LR & total & MC-LR & total & \\
\hline 0 & 99.0 & 243.5 & 3.5 & 6.9 & 0.2 & 0.5 & 3.7 & 7.4 & $<$ LOD \\
\hline 7 & 157.0 & 187.0 & - & - & - & - & - & - & $<$ LOD \\
\hline 14 & 372.1 & 382.3 & 3.3 & 4.6 & 0.5 & 1.0 & 3.8 & 5.6 & 0.14 \\
\hline 21 & 317.1 & 383.9 & 1.5 & 1.9 & 0.5 & 0.9 & 2.1 & 2.8 & 0.12 \\
\hline 28 & 133.4 & 133.4 & 2.8 & 3.6 & 0.1 & 0.1 & 2.9 & 3.7 & 0.23 \\
\hline
\end{tabular}

Sampling and measuring of haematological indicators in blood and biochemical indices in plasma

Immediately after catching the fish (10 individuals from experimental and 10 individuals from the control group) from a pond or tank, blood samples were collected. Inadequate and haemolytic blood samples were eliminated. The fish were sampled at the beginning of the experiment and every $7^{\text {th }}$ day during and after exposure.

Fish blood was taken by cardiopuncture using heparinised syringes. Heparin at a concentration of 50 I.U. per $1 \mathrm{ml}$ was used for blood stabilization. Values of haemoglobin (Hb), haematocrit (PCV), mean corpuscular haemoglobin concentration (MCHC), mean corpuscular volume (MCV), mean corpuscular haemoglobin (MCH), erythrocyte (RBC) and leukocyte (WBC) were determined by standard methods (Svobodová et al. 1991).

The blood was centrifuged at $400 \mathrm{~g}$ for $15 \mathrm{~min}$ at $4{ }^{\circ} \mathrm{C}$, and the resulting plasma was stored at $-80{ }^{\circ} \mathrm{C}$ until the day of analyses. Biochemical analyses of blood plasma were conducted using commercially available reagents (Table 2) using the ADVIA 1650 automatic analyzer (Siemens, USA). All serum enzymatic activities were analyzed at $37^{\circ} \mathrm{C}$.

Table 2. Methods used for biochemical plasma analyses.

\begin{tabular}{|l|l|l|l|}
\hline Constituent & Method & Kit & Reference \\
\hline Acid phosphatase (ACP) & Enzymatic method, 1-naphtyl phosphate & Roche & Hillmann (1971) \\
\hline Albumin (ALB) & Bromcresol green & Skalab, Svitavy & Doumas et al. (1971) \\
\hline Alkaline phosphatase (ALP) & Enzymatic method, AMP buffer & Bayer, Tarrytown & Tietz et al. (1980) \\
\hline Alanine aminotransferase (ALT) & Kinetic UV & Lachema, Brno & Expert panel (1976) \\
\hline Total bilirubin (BIL) & Oxidation, Potassium ferricyanide & Skalab, Svitavy & O'Leary et al. (1993) \\
\hline Creatinine (CRE) & Jaffe, kinetic without deproteination & Bayer, Tarrytown & Jaffe (1886) \\
\hline Aspartate aminotransferase (AST) & Kinetic UV & Lachema, Brno & Expert panel (1976) \\
\hline Calcium (Ca) & Colorimetric method, arzenazo III & Skalab, Svitavy & Ichaylova and Ilkova (1971) \\
\hline Total protein (TP) & Biuret & Lachema, Brno & Doumas et al. (1981) \\
\hline Glucose (GLC) & Colorimetric method, GOD-POD & Lachema, Brno & Barham and Trinder (1972) \\
\hline Magnesium (Mg) & Colorimetric method, arzenazo III & Skalab, Svitavy & Škavrada (1999) \\
\hline Lactate (LACT) & Enzymatic method & Bayer, Tarrytown & Shimojo et al. (1989) \\
\hline Lactate dehydrogenase (LDH) & Enzymatic method, P -> L & Lachema, Brno & Hajzler and Jagelková (1988) \\
\hline Phosphorus (P) & Molybdate UV & Skalab, Svitavy & Kratochvíla and Garčic (1977) \\
\hline Iron (Fe) & Ferene, without deproteination & Skalab, Svitavy & Higgins (1981) \\
\hline Urea (U) & Urease UV & Bayer, Tarrytown & Roch-Ramel (1967) \\
\hline Cholinesterase (CHE) & Kinetic test, butyryl thiocholine & Skalab, Svitavy & Gary (1971) \\
\hline Cholesterol (CHOL) & Enzymatic method, CHOD-PAP & Bayer, Tarrytown & Roeschlau (1974) \\
\hline
\end{tabular}


Statistical analyses

Data were processed in two stages. Significance of differences between every individual experimental and control groups was analysed by $t$-test using the Unistat 5.0 software. Significantly different indices compared to the control are marked by one asterisk $(P<0.05)$ or two asterisks $(P<0.01)$.

To determine the total effect of cyanobacteria in blood, indices were analysed as follows. Firstly, presumption of data normality and skedasticity was verified. The next procedure depended on the presumption: normality and homoskedasticity was followed by F-test, abnormality and homoskedasticity was followed by Kruskal-Wallis test, normality or abnormality and heteroskedasticity were followed by transformation of data (necessary to ensure homoskedasticity) and the selection of a test in compliance with normality. Significant differences of the total effect of cyanobacteria are marked by a diesis (where $P<0.05$ ), and were analysed using the NCSS2000 and SCAN software.

\section{Results and Discussion}

The haematological and biochemical indicators affected by cyanobacterial water bloom are presented in Fig. 1 and Table 3.
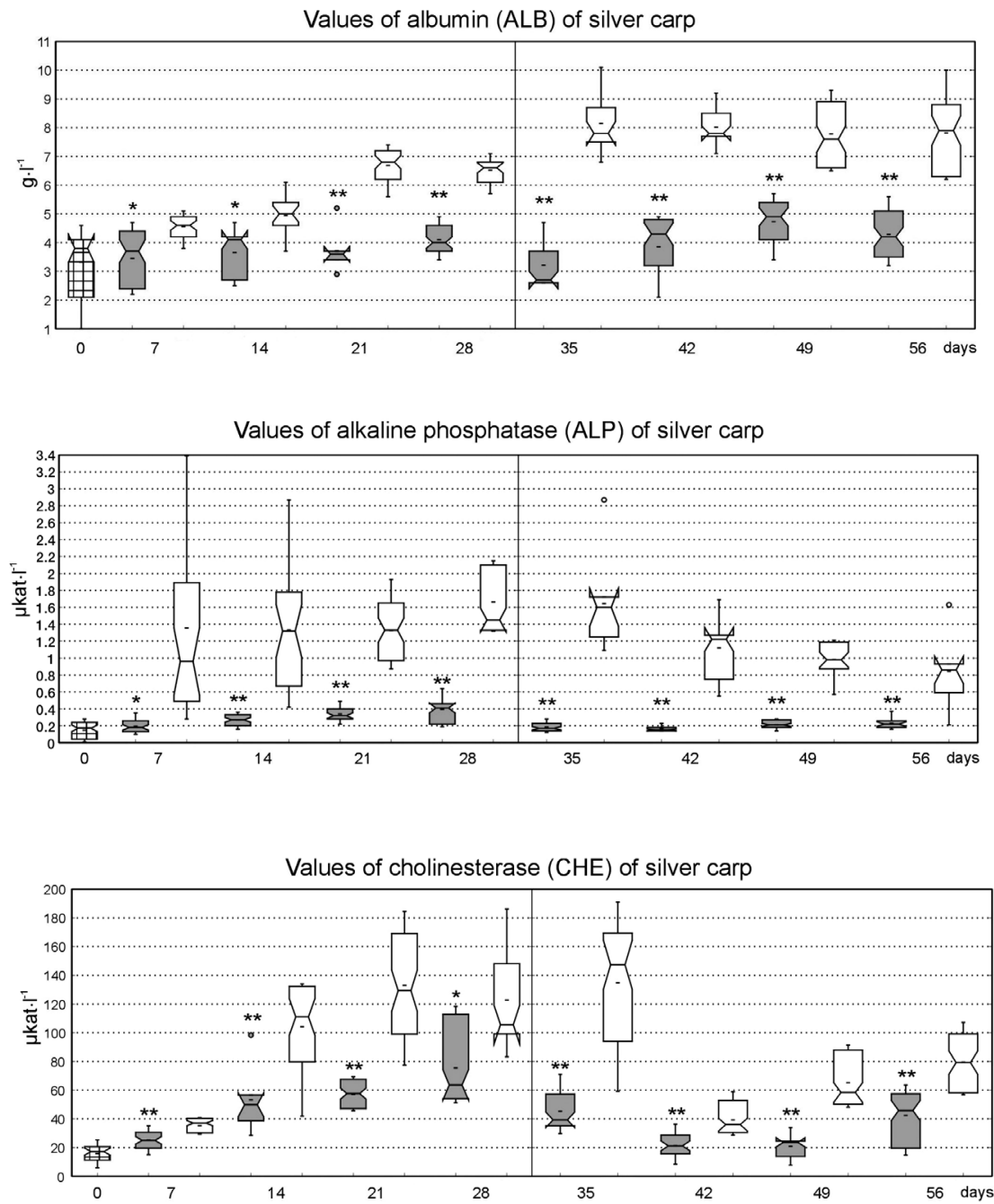
Values of creatinine (CRE) of silver carp

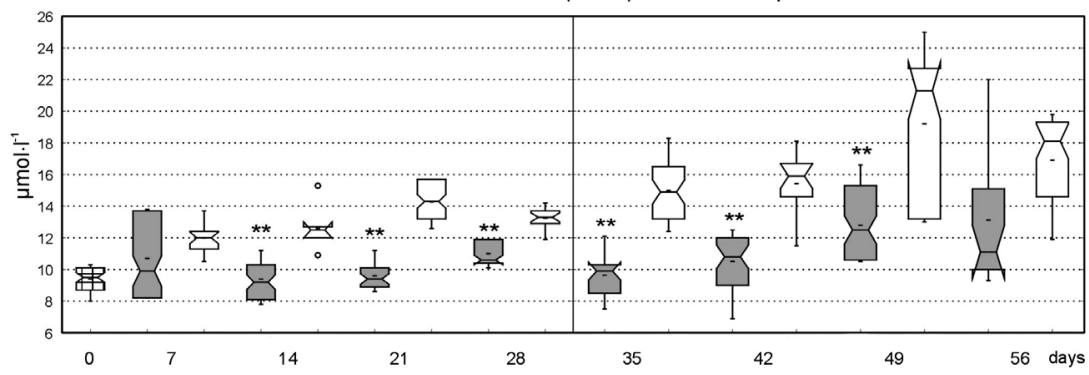

Values of cholesterol (CHOL) of silver carp

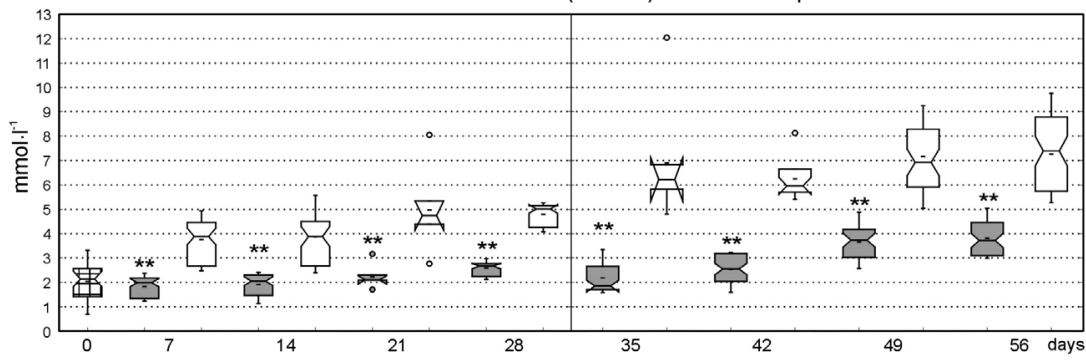

Values of phosphorus $(P)$ of silver carp

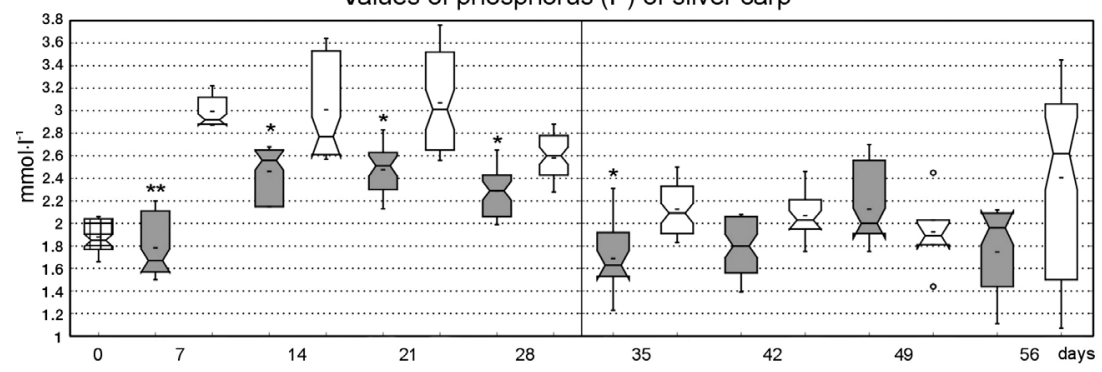

Values of total protein (TP) of silver carp

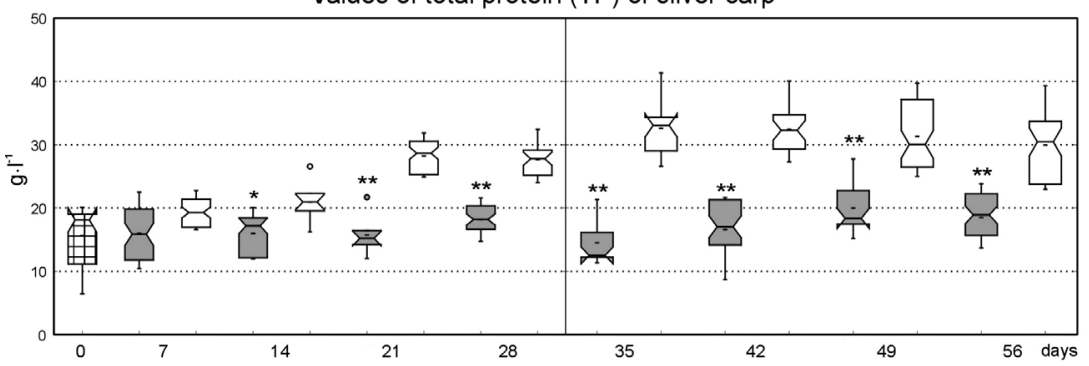

Fig. 1 The effect of cyanobacteria on haematological and biochemical indices of the silver carp. The box plots show the average value (middle line of the box), median value (short line in the box), standard error (notch of the box), the upper and lower interquartile range and the $95 \%$ confidence interval for the interquartile range. Significantly different indices compared to the control are marked by an asterisk when $P<0.05$ or two asterisks when $P<0.01$. The checked box indicates input of data. Open boxes indicate control and tinted boxes indicate experimental groups. The black line in the middle of plots indicates fish transfer to pure water. 
Table 3. The effect of cyanobacteria on haematological blood and biochemical plasma indices of silver carp (average value $\pm \mathrm{SD}$ ). Significantly different influences of cyanobacterial population on haematological and biochemical indices of silver carp $(P<0.05)$, when compared to the control, are marked by diesis in column named Exposure under natural conditions. Influence of cyanobacteria was significantly persistent after a 28-day exposure to silver carps in pure water and is marked by diesis in the column Exposure in pure water.

\begin{tabular}{|c|c|c|c|c|c|}
\hline \multirow[b]{2}{*}{ Constituent } & \multirow[b]{2}{*}{ Unit } & \multicolumn{2}{|c|}{ Exposure under natural conditions } & \multicolumn{2}{|c|}{ Exposure in pure water } \\
\hline & & $\begin{array}{c}\text { Experimental } \\
\mathrm{n}=40\end{array}$ & $\begin{array}{c}\text { Control } \\
\mathrm{n}=40\end{array}$ & $\begin{array}{c}\text { Experimental } \\
\mathrm{n}=40\end{array}$ & $\begin{array}{c}\text { Control } \\
n=40\end{array}$ \\
\hline $\mathrm{ACP}$ & $\mu \mathrm{kat} \cdot \mathrm{l}^{-1}$ & $359.9 \pm 91.5$ & $312.2 \pm 76.7$ & $418.7 \pm 151.6$ & $474.8 \pm 112.8$ \\
\hline ALT & $\mu \mathrm{kat} \cdot \mathrm{l}^{-1}$ & $0.65 \pm 0.50$ \# & $0.50 \pm 0.33$ & $0.22 \pm 0.18^{\#}$ & $0.47 \pm 0.37$ \\
\hline AST & $\mu \mathrm{kat} \cdot \mathrm{l}^{-1}$ & $1.77 \pm 0.90$ & $2.34 \pm 1.17$ & $2.35 \pm 0.74$ & $3.90 \pm 2.22$ \\
\hline BIL & $\mu \mathrm{mol} \cdot 1^{-1}$ & $2.29 \pm 1.04$ & $2.70 \pm 1.75$ & $0.29 \pm 0.36$ & $0.13 \pm 0.26$ \\
\hline $\mathrm{Ca}$ & $\mathrm{mmol} \cdot \mathrm{l}^{-1}$ & $2.30 \pm 0.27$ & $2.47 \pm 0.21$ & $2.19 \pm 0.26$ & $2.44 \pm 0.23$ \\
\hline $\mathrm{Mg}$ & $\mathrm{mmol} \cdot \mathrm{l}^{-1}$ & $1.19 \pm 0.17$ & $1.21 \pm 0.18$ & $0.92 \pm 0.17$ & $1.05 \pm 0.24$ \\
\hline GLC & $\mathrm{mmol} \cdot \mathrm{l}^{-1}$ & $2.60 \pm 0.70^{\#}$ & $3.86 \pm 0.95$ & $4.10 \pm 1.18^{\#}$ & $5.61 \pm 1.60$ \\
\hline LACT & $\mathrm{mmol} \cdot 1^{-1}$ & $5.09 \pm 1.42^{\#}$ & $5.67 \pm 1.08$ & $2.75 \pm 1.90$ & $3.48 \pm 1.70$ \\
\hline $\mathrm{LDH}$ & $\mu \mathrm{kat} \cdot 1^{-1}$ & $10.33 \pm 3.82^{\#}$ & $13.05 \pm 5.38$ & $14.71 \pm 7.84$ & $25.15 \pm 29.94$ \\
\hline $\mathrm{Fe}$ & $\mu \mathrm{mol} \cdot 1^{-1}$ & $9.42 \pm 2.70^{\#}$ & $13.57 \pm 5.77$ & $8.06 \pm 2.79^{\#}$ & $12.61 \pm 4.55$ \\
\hline $\mathrm{U}$ & $\mathrm{mmol} \cdot \mathrm{l}^{-1}$ & $0.39 \pm 0.18$ & $0.52 \pm 0.23$ & $0.48 \pm 0.35$ & $0.69 \pm 0.29$ \\
\hline $\mathrm{Hb}$ & $\mathrm{g} \cdot \mathrm{l}^{-1}$ & $50.9 \pm 13.3^{\#}$ & $60.2 \pm 12.2$ & $75.8 \pm 14.6^{\#}$ & $55.5 \pm 13.5$ \\
\hline PCV & $1 \cdot 1^{-1}$ & $0.23 \pm 0.05^{\#}$ & $0.29 \pm 0.06$ & $0.20 \pm 0.05^{\#}$ & $0.32 \pm 0.06$ \\
\hline $\mathrm{MCV}$ & $\mathrm{fl}$ & $180 \pm 29$ & $177 \pm 25$ & $155 \pm 22$ & $157 \pm 18$ \\
\hline $\mathrm{MCH}$ & $\mathrm{pg}$ & $40 \pm 13$ & $37 \pm 5$ & $66 \pm 25$ & $28 \pm 11$ \\
\hline $\mathrm{MCHC}$ & $1 \cdot 1^{-1}$ & $0.22 \pm 0.05$ & $0.21 \pm 0.02$ & $0.40 \pm 0.15$ & $0.18 \pm 0.05$ \\
\hline $\mathrm{RBC}$ & $\mathrm{T} \cdot \mathrm{l}^{-1}$ & $1.30 \pm 0.30^{\#}$ & $1.70 \pm 0.39$ & $1.29 \pm 0.41^{\#}$ & $2.08 \pm 0.41$ \\
\hline WBC & $\mathrm{G} \cdot \mathrm{l}^{-1}$ & $73 \pm 31^{\#}$ & $89 \pm 37$ & $37 \pm 17^{\#}$ & $24 \pm 8$ \\
\hline
\end{tabular}

Total statistical evaluation of the influence of cyanobacterial water bloom on biochemical indices of the two-year-old silver carp showed a distinct decrease of albumin, alkaline phosphatase, cholesterol, total protein, glucose, creatinine, lactate, lactate dehydrogenase, phosphorus, iron, cholinesterase, haemoglobin, haematocrit, erythrocyte and leukocyte compared to controls. Values of alanine transaminase were significantly increased compared to controls. Changes of total bilirubin, aspartate aminotransferase, calcium, magnesium, urea, mean corpuscular haemoglobin concentration, mean corpuscular volume and mean corpuscular haemoglobin were not significantly elevated or decreased compared to controls.

Values of haematological and biochemical indices in this work do not correspond well with the results published by other authors (Rabergh et al. 1991; Tencalla et al. 1994; Carbis et al. 1996, 1997; Navrátil et al. 1998; Kopp and Heteša, 2000; Kopp et al. 2005; Li et al. 2004, 2007; Zhang et al. 2008; Qiu et al. 2009). Differences were mainly due to the different ways of toxin and cyanobacterial cell biomass administration, alterations in the physiological status of the cyanobacterial water bloom populations and different sensibility of fish species.

Significance of the differences between individual groups was analysed every 7 days of the experiment, not always corresponding with the overall statistical evaluation. Values of ALB, ALP, CHOL, CHE and P, were significantly different every week of the experiment under natural conditions (Fig. 1), whereas values of the ALT, LACT, LDH, Fe, Hb, PCV and $\mathrm{WBC}$ were significant only once during exposure to natural conditions.

Liver enzymes (ALT, AST and LDH) are the most frequently tested enzymes in fish for indication of cyanobacterial toxicity. Rabergh et al. 1991 reported that the activity of blood plasma enzymes (ALT, AST and LDH) increased $2 \mathrm{~h}$ after intraperitoneal injection 
of a toxin as a result of hepatocyte necrosis. Tencalla et al. (1994) observed a decrease in their activity after $48 \mathrm{~h}$, and suggested that this was due to damage to a majority of hepatocytes that were not able to release enzymes into the circulatory system. A significant increase in the activities of ALT, AST and LDH after intraperitoneal or oral administration of microcystin-LR to the carp was observed (Bury et al. 1997; Navrátil et al. 1998; Malbrouck et al. 2003; Li et al. 2004). Kopp and Heteša (2000) reported that the activity of blood plasma enzymes increased after exposing the common carp for 96-h to natural cyanobacterial population. Carbis et al. (1996) noted a delay of toxic manifestation in fish exposed to water with dispersed microcystin. Serum activities of AST and ALT increased 7 days after the carp were exposed to water that contained microcystins. Feral carp from a lake where toxic Microcystis aeruginosa was formed had a higher activity of AST in serum (Carbis et al. 1997). Qiu et al. (2009) observed increased activity values of LDH and decreased values of AST and ALT in silver carp and bighead carp during exposure to cyanobacteria in natural environment. Malbrouck et al. (2003) reported that activities of plasma enzymes (ALT, AST and LDH) completely recovered after 21 days of intraperitoneal injection of microcystin-LR.

Our results showed a significant increase $(P<0.05)$ in values of ALT during exposure to cyanobacteria and a significant decrease after transfer to pure water (Table 3 ). Values of LDH decreased significantly during exposure to cyanobacteria; these values did not change significantly after transfer to pure water. Values of AST were lower in the experimental group compared to the control group during the entire experiment, but the changes were not significant.

Daily low dose of exposure of fish to cyanobacteria containing microcystins caused inexpressive changes in serum, ALT, AST and LDH activities. The absorption of common concentrations of microcystins in natural water through oral, dermal or brachial pathways may be limited in healthy fish. The acute toxicity of microcystins is unlikely to occur in silver carp and chronic injury will probably not be detected by changes of enzyme (AST, ALT and LDH) activity in the blood plasma.

Compared to the control fish, exposure to cyanobacteria had significant decreasing effects on the serum ALP, CRE and CHE activity. An increased value of alkaline phosphatase indicates incorrect secretion of bile. The decrease of cholinesterase values may indicate chronic injury of the hepatopancreas. An increased value of creatinine is an indicator of kidney damage, muscular dystrophia and exercise of the organism (Masopust 1998). Kopp et al. (2005) showed that in silver carp exposed to toxic cyanobacterial population, serum activities of ALP significantly decreased, and activities of CHE significantly increased. The ALP activities of carp did not change in water that contained the pesticide diazinon (Lusková et al. 2002). Our results of alkaline phosphatase and creatinine activities support the assumption that the liver and muscle tissues of experimental fish were not markedly affected. On the other hand, decreased values of cholinesterase observed in the experimental silver carp groups indicate that the toxic population of cyanobacteria damages the hepatopancreas.

Bury et al. (1996) and Ernst et al. (2006) observed slightly increased glucose concentrations in fish (brown trout and whitefish, respectively) exposed to cyanobacteria, but changes were not significant. An increase in glucose is a general response of fish to acute pollutant effects and stress (Lusková et al. 2002; Svobodová et al. 2006). Consequently, stress as indicated by plasma glucose changes does not appear to be associated with liver pathology. The significant decrease of glucose in our experiment may be affected by a high concentration of cyanobacteria cells in water, difficult respiration, poor availability of nutrition and increased consumption of energy for basic metabolism. The values of glucose changed again after transfer to pure water.

Blood cell components ( $\mathrm{Hb}, \mathrm{PCV}, \mathrm{RBC}, \mathrm{MCV}, \mathrm{MCH}$ and $\mathrm{MCHC}$ ) usually decrease 
after application of pure microcystins or toxic cyanobacterial biomass as a result of patho-morphological changes. These comprise extensive haemorrhage of the skin, eyes, hepatopancreas and swim bladder (Navrátil et al. 1998; Vajcová et al. 1998). Our results showed an overall significant decrease in values of $\mathrm{Hb}, \mathrm{PCV}$ and $\mathrm{RBC}$ in the statistical evaluation. This decrease was also noted after transfer to pure water, with the exception of $\mathrm{Hb}$ values, which were significantly elevated. Natural populations of cyanobacteria in water do not create extensive injury to fish, although their effect on environmental conditions (e.g. dissolved oxygen and ammonia) is detrimental to the health of fish. Cyanobacterial biomass caused fluctuation of oxygen saturation of water, and as a possible result of compensation for the deficiency of oxygen, fish were found to have higher counts of haemoglobin. Small differences among biochemical indices in a population of fish are normal.

Asignificant decrease in the total leukocyte count (WBC) was observed after intraperitoneal or oral administration of microcystin-LR in the carp (Palíková et al. 1998). Our results showed a significant decrease in the value of total leukocyte counts in natural water and a significant increase after transfer to pure water. It should be noted that the leukocyte counts in blood were higher in the control and experimental groups of silver carp under natural water conditions compared to both groups of fish in pure water.

In previous experiments, values of total protein significantly decreased after intraperitoneal administration of pure microcystin-LR to the common carp (Navrátil et al. 1998), silver carp (Vaj cová et al. 1998) and were not changed in the carp (Carbis et al. 1996). Changes of total protein under the influence of cyanobacterial populations were reduced in the common carp (Kopp and Heteša 2000) and were not changed in the silver carp (Kopp et al. 2005). The values of total protein concentration in our experiment were significantly decreased. Changes in protein content started immediately after the beginning of exposure. The values of total protein significantly differ every week during natural exposure, as well as after the transfer of fish into pure water (Fig. 1).

Likewise, the practically identical values of urea, observed in the control and experimental silver carp groups, indicate that the metabolism of proteins was not damaged by the toxic population of cyanobacteria. On the other hand, urea values were significantly increased during a study on silver carp and bighead carp under natural conditions in China (Qiu et al. 2009). Our results showed a significant decrease in values of albumin compared to control. Significant changes in individual weeks were apparent immediately and the values of albumin were persistent after fish were transferred to pure water. Lower values of albumin may indicate insufficient liver activity but the decline in values may be affected by other factors. Albumin values were within the normal range during a study of feral carp (Carbis et al. 1997) and silver carp (Kopp et al. 2005) under the influence of microcystins. Changes in the values of albumin in carp were not observed even after intraperitoneal application of microcystins (Carbis et al. 1996). Microcystins alone thus do not influence the values of albumin and the decline of values may be affected by another cyanobacterial metabolite.

Most authors have reported an increase in plasma lactate concentration in various fish following stress and acute effects of toxic substances including bacterial toxins (Dabrowska et al. 1991; Kakuta et al. 1991; Williams et al. 1997; Kopp et al. 2005). In contrast, Lusková et al. (2002) reported a decrease of plasma lactate concentration in carp kept in water containing the pesticide diazinon. In our experiment, a significant decrease of lactate concentration in the blood plasma of experimental fish compared to control may indicate a higher metabolic rate of lactate in the hepatopancreas and/or it might be a result of stress caused by cyanobacteria. The decline in the lactate value was slow but not significantly after the transfer of fish to pure water.

The negative effect of different pollutants at sublethal concentrations and stress of fish 
may be indicated by a decrease in cholesterol values (Gluth and Hanke 1985; Svobodová et al. 2006). The decrease in cholesterol concentrations in our study may indicate a slight injury of the hepatopancreas. Significant changes in cholesterol started after 7 days of exposure to cyanobacteria and remained significant even after the transfer of fish to pure water. The same trends in cholesterol values were described by Zhang et al. (2007) in crucian carp and by Qiu et al. (2009) in silver carp and bighead carp.

Our results showed a significant decrease in electrolyte values (Fe and P) after 7-28 days of exposure of the fish to cyanobacteria, values of $\mathrm{Mg}$ and $\mathrm{Ca}$ decreased, although not significantly compared to the control. Kopp et al. (2005) reported a significant decrease in values of $\mathrm{Ca}$, and $\mathrm{Mg}$, and a significant increase in Fe and $\mathrm{P}$ in silver carp under the influence of a natural cyanobacteria population. Lusková et al. (2002) reported that the content of $\mathrm{Ca}$ and $\mathrm{P}$ in the blood plasma of carp decreased in water containing pesticide. The basic function of electrolytes in the body is to control fluid distribution, intra- and extra-cellular acidobasic balance, maintaining osmotic pressure of body fluids and normal neuro-muscular irritability. Calcium and phosphorus ions functionally participate in maintaining normal irritability of the heart, muscles and nerves, as well as the selective permeability of cell membranes. Magnesium and iron are important for a healthy function of the kidneys, liver and proteosynthesis. Decreased or increased values of electrolytes in blood plasma indicated abnormal function of the fish organism. The values of electrolytes were not significantly changed 7-14 days after fish transfer to pure water. After this period, differences between experimental and control groups of fish were noted. The following differences in values of electrolytes (21-28 days after transfer) could be caused by other factors (stress in pure water, absence of nutrition, etc.).

Biochemical indices of blood and plasma in fish are affected by many endogenous and exogenous factors. Liver enzymes (ALT, AST and LDH) are the most suitable variables in fish as indicators of the toxicity of cyanobacteria after intraperitoneal or per os biomass administration. The toxic effect of cyanobacteria on fish exposed to natural environmental conditions is much weaker than after intraperitoneal or per os administration. In case of chronic exposure, cyanobacteria will most likely not be detected by enzyme activity changes (ALT, AST, ALP, ACP, CHE and LDH) in the blood plasma of fish. Our results proved that liver damage was not severe enough to cause changes in the activities of liver enzymes. Other indicators, Hb, RBC, WBC, PCV, TP, LACT, Fe, P and GLU were influenced by the action of natural population of cyanobacterial water bloom due to the participation of other active substances and changes in water chemistry. Measurements of albumin, alkaline phosphatase, cholinesterase and cholesterol in blood serum are therefore recommended under natural conditions.

\section{Změny hematologických a biochemických ukazatelů u tolstolobika bílého (Hypophthalmichthys molitrix Val.) pod vlivem toxického vodního květu sinic}

Cílem předložené práce bylo sledovat vliv toxické populace vodního květu sinic na hematologické ukazatele u dvouletého tolstolobika bílého (celková délka $336 \pm 32 \mathrm{~mm}$, celková hmotnost $365 \pm 112 \mathrm{~g}$ ). Změny byly sledovány u ryb exponovaných $\mathrm{v}$ sádce $\mathrm{s}$ masivně přirozeně vyvinutým toxickým vodním květem sinic a porovnávány s rybami kontrolními exponovanými v sádce bez sinic. Vodní květ sinic byl tvořen koloniálními sinicemi Microcystis aeruginosa a Microcystis ichthyoblabe obsahujících mikrocystiny v celkové koncentraci $2,8-7,4 \mu \mathrm{g} \cdot \mathrm{l}^{-1}$ ve vodě a $133-284 \mu \mathrm{g} \cdot \mathrm{g}^{-1} \mathrm{v}$ sušině biomasy. Statistické vyhodnocení výsledků ukázalo signifikantní pokles hodnot albuminu, alkalické fosfatázy, cholesterolu, glukózy, celkového proteinu, kreatininu, laktátu, laktát dehydrogenázy, fosforu, železa, cholinesterázy, hemoglobinu, hematokritu, erytrocytů, leukocytů a signifikantní zvýšení alanin aminotransferázy u ryb exponovaných v sinicích ve srovnání s kontrolními 
rybami. Po expozici byly pokusné i kontrolní ryby přemístěny do čisté vody bez sinic a řas ke sledování perzistence působení sinic na hematologické ukazatele. U hodnot albuminu, alkalické fosfatázy, cholesterolu, glukózy, celkového proteinu, kreatininu, fosforu, železa, cholinesterázy, hematokritu a erytrocytů přetrvával vliv sinic i v průběhu 28 dnů po ukončení expozice. Expoziční doba, toxicita a hustota vodního květu sinic má výrazný vliv na jednotlivé hematologické ukazatele.

\section{Acknowledgements}

This work was supported by the research project funded by the Ministry of Education, Youth and Sports of the Czech Republic "Veterinary aspects of food safety and quality" (MSM 62 15712402) and by the National Agency for Agricultural Research (QH71015).

Help from the Centre for Cyanobacteria and their Toxins (Recetox, Brno) in the analyses of microcystins is appreciated.

\section{References}

APHA 1981: Standard methods for the examination of water and wastewater $\left(15^{\text {th }}\right.$ edn $)$ American public Health Association Inc., Washington D.C.

Barham D, Trinder P 1972: An improved colour reagent for the determination of blood glucose by the oxidase system. Analyst 97: 142-145

Bláha L, Maršálek B 2003: Contamination of drinking water in the Czech Republic by microcystins, Arch Hydrobiol 158: 421-429

Bury NR, Eddy FB, Codd GA 1996: Stress Responses of Brown Trout, Salmo Trutta L., to the Cyanobacterium, Microcystis aeruginosa. Environ Toxicol Water Qual 11: 187-193

Bury NR, McGeer JC, Eddy FB, Codd GA 1997: Liver damage in brown trout, Salmo trutta L., and rainbow trout, Oncorhynchus mykiss (Walbaum), following administration of the cyanobacterial hepatotoxin microcystin-LR via the dorsal aorta. J Fish Dis 20: 209-215

Carbis CR, Mitchell GF, Anderson JW, McCauley I 1996: The effects of microcystins on the serum biochemistry of carp, Cyprinus carpio L., when the toxins are administered by gavage, immersion and intraperitoneal routes, J Fish Dis 19: 151-159

Carbis CR, Rawlin GT, Grant P, Mitchell GF, Anderson JW, McCauley I 1997: A study of feral carp, Cyprinus carpio L., exposed to Microcystis aeruginosa at Lake Mokoan, Australia, and possible implications for fish health. J Fish Dis 20: 81-91

Chorus I, Bartram J 1999: Toxic Cyanobacterium in Water: A Guide to their Public Health Consequences, Monitoring and Management. London: E\&FN Spon (published on behalf of the WHO)

Chorus I, Falconer IR, Salas HJ, Bartram J 2000: Health risk caused by freshwater cyanobacteria in recreation waters. J Toxicol Environ Health 3: 361-377

Dabrowska H, Dabrowski K, Meyer-Burgdorff K, Hanke W, Gunther KD 1991: The effect of large doses of vitamin $\mathrm{C}$ and magnesium on stress responses in common carp, Cyprinus carpio. Comp Biochem Physiol A-Mol Integr Physiol 99: 681-685

Dobšíková R, Svobodová Z, Bláhová J, Modrá H, Velíšek J 2006: Stress response to long distance transportation of common carp (Cyprinus carpio L.) Acta Vet Brno 75: 437-448

Doumas BT, Watson WA, Biggs HG 1971: Albumin standards and the measurement of serum albumin with bromcresol green. Clin Chim Acta 31: 87-96

Doumas BT, Bayse DD, Carter RJ, Peters TJR, Schaffer RA 1981: Candidate reference method for determination of total protein in serum. I. Development and validation. Clin Chem 16: 42-50

Ernst B, Hoeger JS, O’Brien E, Dietrich RD 2006: Oral toxicity of the microcystins-containing cyanobacterium Planktothrix rubescens in European whitefish (Coregonus lavaretus). Aquat Toxicol 79: 31-40

Expert Panel on Enzymes of The IFCC 1976: Methods for the measurement of catalytic concentration of enzymes, Part 2. Clin Chim Acta 70, 19-42

Garry PJ 1971: A Manual and Automated Procedure for Measuring Serum Cholinesterase Activity and Identifying Enzyme Variants. Clin Chem 17: 192-198

Gluth G, Hanke W 1985: A comparison of physiological changes in carp, Cyprinus carpio, induced by several pollutants at sublethal concentrations. Ecotox Environ Safe 9: 179-188

Hajzer S, Jagelková J 1988: Proposition of standard method for catalytic concentration of lactate dehydrogenase in plasma diagnosis. Biochem Clin Bohemoslov 17: 371-379 (in Slovak)

Higgins T 1981: Novel chromogen for serum iron determinations. Clin. Chem. 9: 1619-1620

Hillmann G 1971: Fortlaufende photometrische Messung der sauren Prostataphosphatase-Aktivität. Z Klin Chem Klin Biochem 9: 273-274 (in German)

Ichaylova V, Ilkova P 1971: Photometric determination of micro amounts of calcium with arsenazo III. Anal Chim Acta 53: 194-198 
ISO 10260 1992: Water quality - Measurement of biochemical parameters - Spectrometric determination of the chlorophyll-a concentration, Int Org Standard Geneva 1992, 6 p.

Jaffe MZ 1886: Ueber den Niederschlag, welchen Pikrinsaure in normalem Harn erzeugt and ueber eine Reaction des Kreatinins. Zeitschrift Für Physiologische Chemie 10: 391-400 (in German)

Kakuta I, Namba K, Uematsu K, Murachi S 1991: Physiological response of the fish, Cyprinus carpio, to formalin exposure - I. Effects of formalin on urine flow, heart rate, respiration. Comp Biochem Physiol C-Toxicol Pharmacol 100: 405-411

Kopp R, Heteša J 2000: Changes of haematological indices of juvenile carp (Cyprinus carpio L.) under the influence of natural populations of cyanobacterial water blooms, Acta Vet Brno 69: 131-137

Kopp R, Mareš J, Kubíček Z, Babica P 2005: The influence of toxic cyanobacterial water blooms on the hematological indicators of silver carp (Hypophthalmichthys molitrix Val.). Oceanological and Hydrobiological Studies 34: 85-92

Kratochvíla J, Garčic A 1977: Assignment of organic phosphorus in biological matter. Biochem Clin Bohemoslov 6: 65-77 (in Czech)

Landsberg JH 2002: The effects of harmful algal blooms on aquatic organisms. Rev Fish Sci 10: 113-390

Li XY, Chung IK, Kim JI, Lee JA 2004: Subchronic oral toxicity of microcystin in common carp (Cyprinus carpio L.) exposed to Microcystis under laboratory conditions, Toxicon 44: 821-827

Li L, Xie P, Li S, Qiu T, Guo L 2007: Sequential ultrastructural and biochemical changes induced in vivo by the hepatoxic microcystins in liver of the phytoplanktivorous silver carp Hypophthalmichthys molitrix. Comp Biochem Physiol C-Toxicol Pharmacol 146: 357-367

Lusková V, Svoboda M, Kolařová J 2002: The Effect of Diazinon on Blood Plasma Biochemistry on Carp (Cyprinus carpio L.). Acta Vet Brno 71: 117-123

Malbrouck C, Kestemont P 2006: Effects of microcystins on fish. Environ. Toxicol. Chem. 25: 72-86

Malbrouck C, Trausch G, Devos P, Kestemont P 2003: Hepatic accumulation and effects of microcystins-LR on juvenilie goldfish Carassius auratus L. Comp Biochem Physiol C-Toxicol Pharmacol 135: 39-48

Maršálek B, Bláha L, Turánek J, Neča J 2001: Microcystin-LR and total microcystins in cyanobacterial blooms in the Czech Republic 1993-2000. Cyanotoxins - Occurrence, Causes, Consequences. I Chorus Berlin, Germany, Springer-Verlag: pp. 56-62.

Masopust J 1998: Clinical biochemistry. Demanding and evaluation of biochemical investigation. Karolinum Praha, 832 p. (in Czech)

Navrátil S, Palíková M, Vajcová V 1998: The Effect of Pure Microcystin LR and Biomass of Blue-green Algae on Blood indices of Carp (Cyprinus carpio L.). Acta Vet Brno 67: 273-279

O’Leary N, Pembroke A, Duggan PF 1993: A robust procedure for the automated masurement of total serum bilirubin using potassium ferricyanide. Ann Clin Biochem 30: 175-179

Palíková M, Kovářů F, Navrátil S, Kubala L, Pešák S, Vajcová V 1998: The Effects of Pure Microcystin LR and Biomass of Blue-green Algae on Selected Immunological Indices of Carp (Cyprinus carpio L.) and Silver Carp (Hypophthalmichthys molitrix Val.). Acta Vet Brno 67: 265-272

Pepeljnjak S, Petrinec Z, Kovacic S, Segvic M 2003: Screening toxicity study in young carp (Cyprinus carpio L.) on feed amended with fumonisin B-1. Mycopathologia 156: 139-145

Qiu T, Xie P, Guo L, Zhang D 2009: Plasma biochemical responses of the plaktivorous filter-feeding silver carp (Hypophthalmichthys molitrix) and bighead carp (Aristichthys nobilis) to prolonged toxic cyanobacterial blooms in natural water. Environ Toxicol Pharmacol 27: 350-357

Rabergh CMI, Bylund G, Eriksson JE 1991: Histopathological effect of microcystin LR a cyclic polypeptide from the cyanobacterium Microcystis aeruginosa on common carp (Cyprinus carpio L.). Aquat Toxicol 20: 131-146

Roch-Ramel F 1967: An enzymic and fluorophotometric method for estimating urea concentrations in nanoliter specimens. Anal Biochem 21: 372-381

Roeschlau P, Bernt E, Gruber WJ 1974: Enzymatic determination of total cholesterol in serum. Clin Chem Clin Biochem 12: 226

Serpunin G 1995: The connection between carp haematological indicators and its growth rate and its well-fedness. In: Proceedings of the $4^{\text {th }}$ Ichtyohaematological Conference Hluboká nad Vltavou, Czech Republic, pp. 21-22

Shen Q, Hu J, Li DH, Wang GH, Liu YD 2005: Investigation on intake, accumulation and toxicity of microcystins to silver carp. Fresenius Environ Bull 14: 1124-1128

Shimojo NK, Nakajima C, Yoshikawa C, Okuda K, Okada K 1989: Test-strip method for measuring lactate in whole blood, Clin Chem 35: 1992-1994

Světina A, Matasin Z, Tofant A, Vucemilo M, Fijan N 2002: Haematology and some blood chemical parameters of young carp till the age of three years. Acta Vet Hung 50: 459-467

Svobodová Z, Vykusová B, Modrá H, Jarkovský J, Smutná M 2006: Haematological and biochemical profile of harvest-size carp during harvest and post-harvest storage. Aquac Res 37: 959-965

Svobodová Z, Pravda D, Paláčková J 1991: Unified methods of haematological examination of fish. Research Institute of Fish Culture and Hydrobiology, Vodnany, Edition Methods, No 22, 31 p.

Škavrada J 1999: Diagnostic agent for magnesium determination. Utility model CZ 8152 U1 (in Czech)

Tencalla GF, Dietrich RD, Schlatter CH 1994: Toxicity of Microcystis aeruginosa peptide toxin to yearling rainbow trout (Oncorhynchus mykiss). Aquat Toxicol 30: 215-224 
Tietz NW (Ed.) 1980: Progress in the development of a recommended method for alkaline phosphatase activity measurements. Clin Chem 26: 1023

Vajcová V, Navrátil S, Palíková M 1998: The Effect of Intraperitoneally Applied Pure Microcystin LR on Haematological, Biochemical and Morphological Indices of Silver Carp (Hypophthalmichthys molitrix Val.). Acta Vet Brno 67: 281-287

Williams EM, Nelson JA, Heisler N 1997: Cardio-respiratory function in carp exposed to environmental nitrite. J Fish Biol 50: 137-149

Zhang X, Xie P, Wang W, Li D, Shi Z 2008: Plasma biochemical responses of the omnivorous crucian carp (Carassius auratus) to crude cyanobacterial extracts. Fish Physiol Biochem 34: 323-329 